\title{
Implementasi Model Pembelajaran Problem Based Learning Untuk Meningkatkan Hasil Belajar Siswa Kelas VII MTs Muhammadiyah Kota Bima
}

\author{
Amran $^{1}$, Nehru $^{2}$, Olahairullah $^{3}$, Erni Suryani ${ }^{4}$ \\ ${ }^{1234}$ Program Studi Pendidikan Biologi, STKIP Bima \\ Email: mpdnehru@gmail.com
}

\begin{abstract}
Abstrak
Penelitian tindakan kelas ini bertujuan untuk mengetahui implementasi model pembelajaran Problem Based Learning dalam meningkatan hasil belajar siswa Kelas VII MTs Muhammadiyah Kota Bima. Penelitian dilakukan di MTs Muhammadiyah Kota Bima, subjek dalam penelitian ini adalah siswa Kelas VII sebanyak 30 orang. Pelaksanaan penelitian ini terdiri dari tiga siklus. Instrumen pengumpulan data yang digunakan adalah lembar observasi, tes, dan angket. Analisis data dilakukan dengan statistik deskriptif. Berdasarkan hasil penelitian dan analisis data diperoleh pembelajaran yang berlangsung pada siklus I belum mencapai indikator kerja yang telah ditentukan sebelumnya yaitu ketuntasan belajar siswa baru mencapai ketuntasan klasikal sebesar 66,17\%, pada siklus II juga belum mencapai ketuntasan klasikal yaitu 73,50\%, pada siklus III telah memenuhi ketuntasan klasikal sebesar 88,50\%. Hasil ini menunjukkan bahwa terjadi peningkatan hasil belajar, aktivitas guru dan siswa yang baik terhadap implementasi model pembelajaran Problem Based Learning pada siswa Kelas VII MTs Muhammadiyah Kota Bima.
\end{abstract}

Kata Kunci: Model pembelajaran, Problem based learning, Hasil belajar

\section{PENDAHULUAN}

Dunia pendidikan sekarang dituntut untuk senantiasa melakukan inovasi dalam pembelajaran pada berbagai aspeknya,mulai dari visi, misi, tujuan program, layanan, metode, teknologi, proses sampai evaluasi. Bagi seorang guru pemilihan model pembelajaran hendaknya dilakukan secara cermat agar pilihan itu tepat dan relevan, dengan berbagai aspek pembelajaran yang lain, efisien dan menarik. Lebih dari itu banyak pakar yang menyatakan bahwa sebaik apapun materi pelajaran yang dipersiapkan tanpa diiringi dengan model pembelajaran yang tepat maka pembelajaran kurang mendapatkan hasil yang maksimal

Berdasarkan realita kebanyakan siswa masih kurang antusias dalam menerima pelajaran, mereka lebih bersifat pasif, malas, enggan, takut atau malu untuk menyampaikan pendapatnya saat menjawab soal. Sebagian besar siswa yang kurang mampu dalam memahami pembelajaran IPA terpadu materi sistem otot pada manusia yang dianggap materi yang banyak dan sulit untuk dihafalkan. Masalah yang muncul dari dalam diri siswa tidak hanya disebabkan oleh siswa itu sendiri, tetapi juga didukung oleh ketidak mampuan guru menciptakan situasi pembelajaran yang membawa siswa tertarik pada materi yang diajarkan. Guru memiliki kewajiban untuk melahirkan generasi muda yang berkualitas baik darisegi intelektual maupun dari segi moralnya. Hal ini dapat dilakukan dengan menciptakan pembelajaran yang efektif. Dalam kegiatan pembelajaran terjadi interaksi antara dengan siswa, interaksi guru dengan siswa, maupun interaksi siswa dengan sumber belajar (Fauzia, 2018).

Sementara Anazifa (2016), menyatakan bahwa guru hanya memberikan informasi kepada siswa dengan menggunakan model konvensional. Dengan demikian, penyebab rendahnya tingkat hasil belajar siswa, yaitu pemilihan model pembelajaran guru yang kurang tepat Untuk mengatasi masalah tersebut di atas, maka kemampuan guru dalam meningkatkan pasrtisipasi siswa dalam proses pembelajaran merupakan salah satu aspek yang menentukan keberhasilan proses pembelajaran tersebut. Guru dituntut untuk mampu menerapkan model pembelajaran yang tepat, sehingga tercipta pembelajaran yang aktif, kreatif, dan menyenangkan bagi siswa. Masih banyak ditemukan guru. Untuk membangun daya tarik siswa terhadap sebuah pelajaran, perlu dipilih model pembelajaran yang tepat

Salah satu model pembelajaran yang dapat meningkatkan pembelajaran yang lebih efektif yang dapat mendorong siswa untuk berfikir secara sistematis dalam menghadapi suatu masalah dalam belajar adalah model pembelajaran Problem Based Learning. 
Menurut Hosnan (2014) model Problem Based Learning mencirikan penggunaan masalah kehidupan nyata sebagai sesuatu yang harus dipelajari siswa untuk melatih dan meningkatkan keterampilan berpikir kritis dan pemecahan masalah serta mendapatkan pengetahuan konsepkonsep penting, dimana tugas guru harus memfokuskan diri untuk membantu siswa mencapai keterampilan mengarahkan diri. Oleh karena itu, dalam penelitian ini tindakan yang dipilih untuk memperbaiki pembelajaran oleh guru agar masalah pada siswa dapat tindakan kelas, pengamatan, dan refleksi.

Model pembelajaran Problem Based Learning diharapkan akan dapat merangsang siswa berfikir lebih mandiri dalam situasi berorientasi masalah termasuk didalamnya belajar dan bagaimana belajar. Pembelajaran PBL lebih memberikan kesempatan pada siswa untuk dapat bekerja sama dengan anggota kelompoknya untuk memecahkan suatu masalah yang sulit dipecahkan secara individu.

Oleh karena itu, dalam penelitian tindakan ini yang dipilih untuk memperbaiki pembelajaran adalah mengimplementasikan Pembelajaran Problem Based Learning untuk meningkatkan hasil belajar siswa Kelas VII MTs Muhammadiyah Kota Bima.

\section{METODE}

Penelitian ini merupakan Penelitian Tindakan Kelas, dengan tujuan penelitian, yaitu untuk mengetahui peningkatan hasil belajar siswa dengan menggunakan model pembelajaran Problem Based Learning pada siswa. Penelitian dirancang dalam tiga siklus, dalam tiap siklus terdiri dari empat tahapan yaitu 1) perencanaan tindakan, 2) pelaksanaan tindakan, 3) pengamatan atau observasi 4) refleksi ada penelitian tindakan kelas (Arikunto, 2010). Rincian kegiatan disajikan pada. gambar 1 berikut:

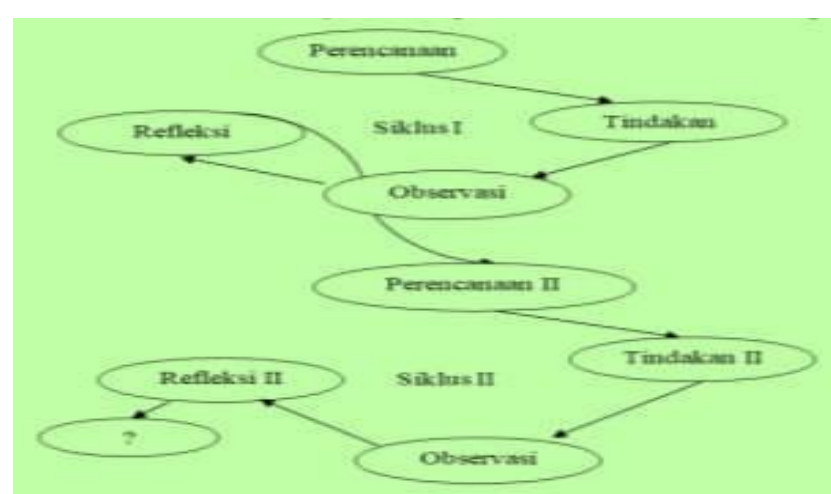

Gambar 1. Siklus Penelitian Tindakan Kelas

Penelitian ini dilakukan di MTs Muhammadiyah Kota Bima dengan subjek penelitian adalah seluruh siswa kelas VII yang berjumlah 30 orang siswa. Data yang diambil berupa hasil belajar siswa yang diperoleh melalui lembar test awal dan test akhir, aktivitas guru dan siswa yang diperlolah dari lembar pengamatan aktivitas guru dan siswa, terhadap model pembelajaran Problem Based Learning. Analisis data dalam penelitian ini menggunakan metode kuantitatif (Sudijono, 2005)

Keterangan:

$$
\mathrm{P}=\frac{f}{N} 100 \%
$$

$$
\begin{aligned}
& \mathrm{P}=\text { persentase yang dicari } \\
& f=\text { frekuensi siswa yang tuntas } \\
& \mathrm{N}=\text { jumlah siswa keseluruhan }
\end{aligned}
$$

Ketuntasan individual dikatakan tercapai apabila skor perolehan siswa lebih besar atau sama dengan KKM, yaitu $\geq 65$, selanjutnya ketuntasan klasikal tercapai apabila siswa mncapai KKM 85\%. Aktivitas guru dan siswa dikatakan baik apabila memperoleh hasil sekurang-kurangnya $75 \%$.

\section{HASIL DAN PEMBAHASAN}

Penelitian tindakan kelas yang dilakukan terdiri dari 3 siklus. Setiap siklus terdiri dari 4 tahapan, yaitu: perencanaan, pelaksanaan,observasi dan refleksi. Subyek dalam penelitian ini adalah seluruh siswa kelas VII yang berjumlah 30 orang siswa. Objek dalam penelitian ini adalah unutk mengetahui hasil belajar siswa menggunakan model pembelajaran Problem Based Learning (PBL). 


\section{Siklus I}

Hasil post test pada siklus I menunjukkan bahwa terdapat 19 siswa yang tuntas secara individual dari 30 siswa. Artinya, secara keseluruhan terdapat $66,33 \%$ siswa yang memperoleh ketuntasan individual, sedangkan ketuntasan klasikal secara keseluruhan sebesar $66,17 \%$. Aktivitas guru selama menggunakan model pembelajaran Problem Based Learning (PBL) dalam proses pembelajaran pada siklus I adalah $65 \%$ dan termasuk kategori cukup baik. Sedangkan, aktivitas siswa selama proses pembelajaran adalah $60 \%$ dan juga termasuk kategori cukup baik. Adapun data hasil penelitian pada siklus I disajikan pada. gambar 2 berikut:

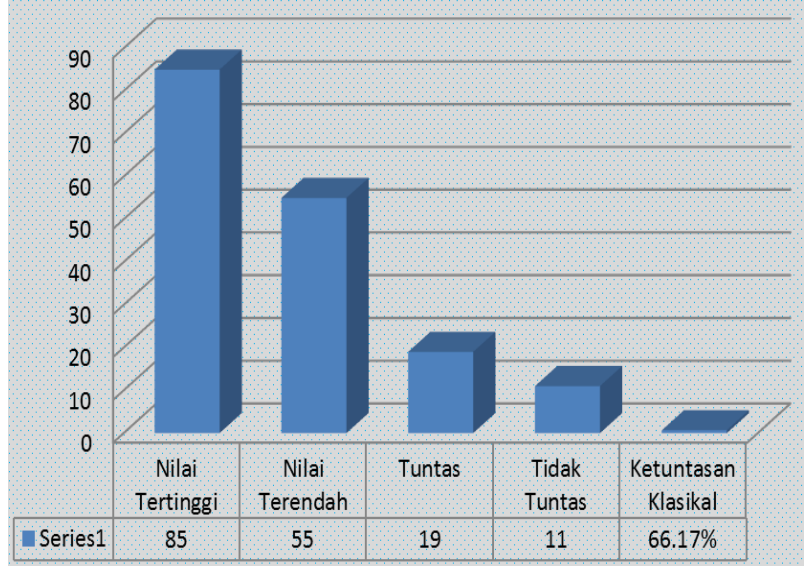

Gambar 2. Data Hasil Belajar Pada Siklus I

Rendahnya hasil belajar pada siklus I ini disebabkan oleh kemampuan dasar dari kebanyakan siswa yang kurang memahami materi, terutama pembagian tugas untuk kelompok penyaji, siswa kurang kompak dalam bekerja kelompok. Hal ini juga terjadi karena guru masih kurang terampil dalam memberikan penguatan materi dan guru belum maksimal dalam memberikan siswa contoh soal yang sesuai dengan materi pembelajaran. 2) Hasil penilaian aktivitas guru dan siswa menunjukkan bahwa terdapat aktivitas guru dan siswa yang masih kurang sehingga diperlukan perbaikan untuk kedepannya.

Berhasil tidaknya suatu pembelajaran di sekolah tidak terlepas dari komponenkomponen pembelajaran, di antaranya; siswa, guru, sarana, materi dan pendekatan atau metode serta strategi pembelajaran yang digunakan dalam menyampaikan materi pembelajaran. Semua komponen tersebut satu sama lain memiliki hubungan yang erat (Djamarah, 2002).

Untuk mengatasi permasalahan tersebut guru perlu mengoptimalkan pembelajaran Problem Based Learning mulai pemberian motivasi kepada siswa, bahwa mereka harus percaya diri, tidak boleh takut dan malu untuk bertanya dan mengemukakan pendapatnya karena didalam proses pembelajaran tetap ada aturan yang menghargai pendapat orang lain walau bagaimana pun bentuk pendapat orang lain tersebut sehingga mengarah kepada suasana yang demokratis (Ahmadi, 2004).

\section{Siklus II}

Setelah dilakukan tindakan perbaikan diperoleh nilai ketuntasan klasikal sebesar adalah 73,50\%. sedangkan siswa yang memenuhi kriteria ketuntasan belajar individu berjumlah 24 orang dari 30 orang siswa, prosentase ketuntasan belajar individu $80,00 \%$. Adapun data hasil penelitian pada siklus II disajikan pada. gambar 3 berikut:

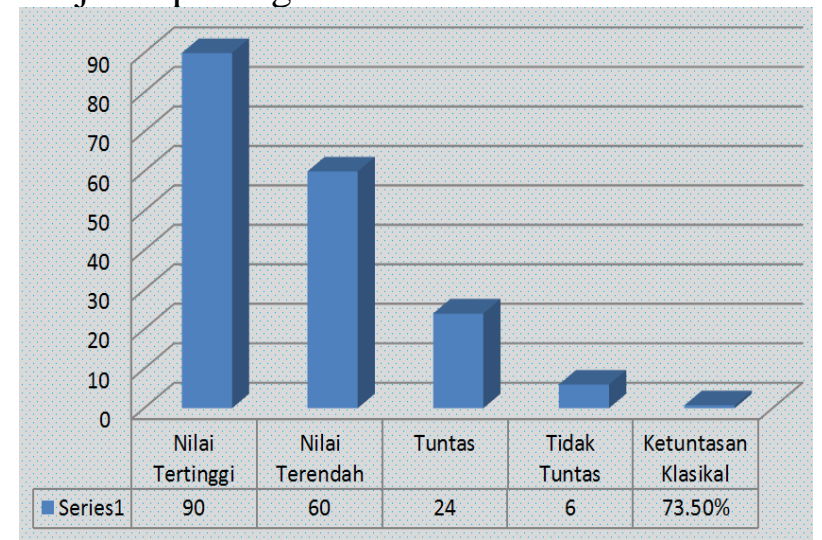

Gambar 3. Data Hasil Belajar Pada Siklus II

Hasil yang didapatkan pada siklus II ini meningkat jika dibandingkan dengan siklus I. Pada hal dari hasil observasi siklus II masih terdapat kekurangan-kekurangan yang muncul pada saat pembelajaran. Hal tersebut disebabkan karena metode Problem Based Learning dapat meningkatkan interaksi dan aktivitas siswa dalam belajar di kelas, untuk dapat aktif dalam pembelajaran siswa harus mempersiapkan diri sebelum menerima pelajaran. Meskipun demikian, pada hasil siklus II ini masih menggambarkan bahwa guru masih belum terampil dalam mengajak siswa aktif dalam pembelajaran karena siswa masih terlihat belum terlibat langsung dalam proses pembelajaran 


\section{Siklus III}

Dari hasil evaluasi siklus III diperoleh nilai ketuntasan klasikal $88,50 \%$ dan siswa yang memenuhi kriteria ketuntasan hasil belajar individu berjumlah 30 orang dari 30 orang siswa, prosentase ketuntasan hasil belajar individu $100 \%$. Hasil ini telah memenuhi indikator kerja yang telah ditentukan sebelumnya yaitu minimal $85 \%$ dari jumlah siswa yang mendapat nilai lebih besar atau sama dengan 65. Adapun data hasil penelitian pada siklus III disajikan pada. gambar 4 berikut:

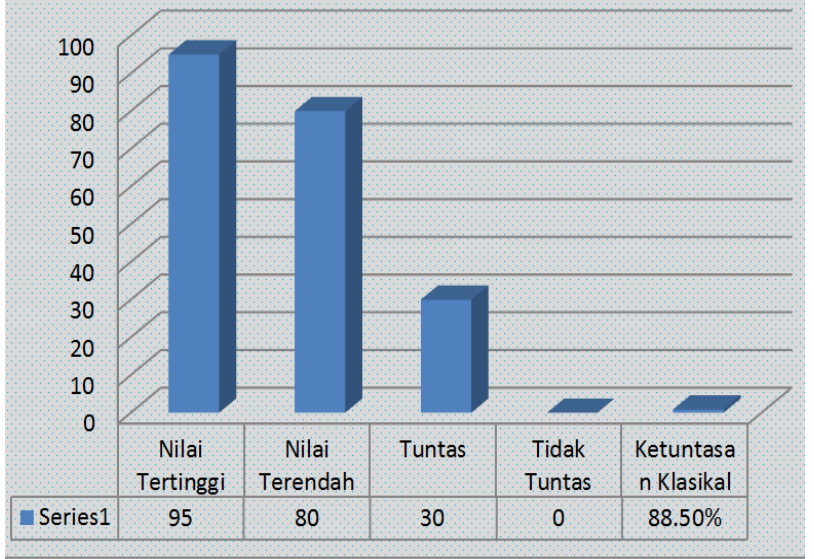

Gambar 4. Data Hasil Belajar Pada Siklus III

Keterampilan guru dalam mengelola pembelajaran menjadi lebih baik dibandingkan dengan siklus sebelumnya. Hal ini ditunjukkan dengan adanya peningkatan skor keterampilan guru yang di siklus I sampai siklus III. Artinya bahwa guru telah berhasil menyajikan pembelajaran sesuai dengan kriteria yang diharapkan. Guru juga sudah mampu memantau kerja siswa pada saat berdiskusi dalam kelompok dan berhasil membuat siswa lebih aktif dan antusias dalam belajar.

Sehingga dapat dikatakan bahwa implementasi model pembelajaran PBL dapat meningkatkan aktivitas dan hasil belajar siswa kelas VII MTs Muhammadiyah Kota Bima. Hal ini disebabkan karena dalam metode Problem Based Learning dapat terjadi interaksi antara siswa dan guru secara baik dan teratur. Dan untuk dapat aktif dalam pembelajaran siswa harus mempersiapkan diri sebelum menerima pelajaran (Djamarah dan Zain, 2002). Hasil ini juga sesuai dengan hasil penelitian yang dilakukan Agustin (2013), Rerung (2017), Supriatna (2020) bahwa ada Peningkatan Aktivitas dan Hasil Belajar Siswa melalui
Model Problem based learning. Penggunaan model Problem Based Learning merupakan proses pembelajaran guru harus menciptakan suasana sedemikian rupa sehingga siswa aktif bertanya, mempertanyakan, dan mengemukakan gagasan. Berdasarkan hasil pengamatan yang dilakukan selama proses pembelajaran berlangsung dengan menerapkan model Problem Based Learning pada siswa kelas VII MTs Muhammadiyah Kota Bima, maka respon siswa yang berkaitan dengan aktivitas belajarnya sudah aktif yaitu antusiasnya dengan mengajukan pertanyaan sangat aktif, menjawan pertanyaan dan mengajukan pendapat aktif, mendengarkan dan kemampuan berkomunikasi sangat baik.

Berdasarkan hasil pada siklus III, maka tindakan dalam siklus diberhentikan karena hasil belajar sudah maksimal semua siswa telah berhasil menuntaskan belajarnya baik secara individual maupun secara klasikal, serta guru telah mampu menerapkan pembelajaran menggunakan model pembelajaran Problem Based Learning dengan sangat baik

\section{KESIMPULAN}

Kesimpulan yang dapat diambil dalam penelitian ini adalah sebagai berikut: pembelajaran yang berlangsung pada siklus I belum mencapai indikator ketuntasan ketuntasan klasikal yaitu sebesar $66,17 \%$, pada siklus II juga belum mencapai ketuntasan klasikal yaitu $73,50 \%$, pada siklus III telah memenuhi ketuntasan klasikal yaitu sebesar $88,50 \%$. Hasil ini menunjukkan bahwa terjadi peningkatan hasil belajar, aktivitas guru dan siswa yang baik terhadap implementasi model pembelajaran Problem Based Learning pada siswa Kelas VII MTs Muhammadiyah Kota Bima.

\section{SARAN}

Adapun saran-saran yang dapat dikemukakan oleh peneliti dari hasil penelitian ini adalah sebagai berikut:

1. Untuk meningkatan kesiapan siswa dalam mempelajari materi sistem otot pada manusia guru sebaiknya menggunakan model pembelajaran Problem Based Learning kepada siswa untuk meningkatkan hasil belajar siswa. 
2. Untuk meningkatkan keaktifan belajar siswa, guru sebaiknya menerapkan model Problem Based Learning dengan memberikan tugas sebelumnya untuk dibahas pada pertemuan berikutnya.

3. Bagi guru atau pihak-pihak yang ingin meneliti lebih lanjut tentang model Problem Based Learning ini diharapkan untuk mencobanya pada materi lain.

\section{UCAPAN TERIMA KASIH}

Ucapan terima kasih kami sampaikan pada guru IPA dan Kepala sekolah MTs Muhammadiyah Kota Bima yang telah membantu dan mengizinkan kami untuk melakukan penelitian.

\section{DAFTAR PUSTAKA}

Agustin, V. N. 2013. Peningkatan Aktivitas dan Hasil Belajar Siswa Melalui Model Problem based learning (PBL). Journal of Elementary Education, 2 (1)

Ahmadi. (2004). Psikologi Belajar. Solo: Rineka Cipta

Anazifa, (2016). "The Effect of Problem Based Learning on Critical Thinking and Student Achievement in the Bantul Senior High School". Paper for an International Conference on Educational Research and Innovation.Journal of Primary Centre Education.1(2): 33-34.

Arikunto, S. (2009). Penelitian Tindakan Kelas.Jakarta: Bumi Aksara.

Djamarah, S.B dan Zain, A. 2002. Strategi Belajar Mengajar. Rineka Cipta: Jakarta

Fauzia, H. A. (2018). Penerapan Model Pembelajaran Problem Based Learning Untuk Meningkatkan Hasil Belajar Matematika SD. Primary: Jurnal Pendidikan Guru Sekolah Dasar, 7(1), 40-47.

Hosnan, M. (2014). Pendekatan Saintifik dan Kontekstual dalam Pembelajaran Abad 21. Bogor: Ghalia Indonesia.

Nafiah, Y. N., \& Suyanto, W. (2014). Penerapan model problem-based learning untuk meningkatkan keterampilan berpikir kritis dan hasil belajar siswa. Jurnal Pendidikan Vokasi, 4(1).

Rerung, N., Sinon, I. L., \& Widyaningsih, S. W. (2017). Penerapan model pembelajaran problem based learning (PBL) untuk meningkatkan hasil belajar peserta didik SMA pada materi usaha dan energi. Jurnal Ilmiah Pendidikan Fisika Al-Biruni, 6(1), 47-55.

Sanjaya, W. (2011). Penelitian Tindakan Kelas.Jakarta.

Sudijono, A. (2005). Pengantar Statistik Pendidikan. Jakarta: Rajawali Pers.

Supriatna, E. (2020). Penerapan Model Pembelajaran Problem Based Learning (PBL) untuk Meningkatkan Hasil Belajar Siswa. Journal of Classroom Action Research, 2(1), 15-19. 